\title{
INTELIGENCJA POLSKA W SŁUŻBIE PAŃSTWOWEJ II RZECZYPOSPOLITEJ (ZARYS PROBLEMATYKI)
}

Streszczenie. Inteligencja polska ukształtowana na przestrzeni XIX w. miała spełniać różnorodne zadania. Jednym z najważniejszych była „służba państwowa”, realizowana między innymi poprzez pracę na państwowych etatach.

Euforii z odzyskanej w $1918 \mathrm{r}$. niepodległości towarzyszyła troska o odpowiednie zorganizowanie państwa, które nie miało nawet ogólnopolskiego rządu, a kilka ośrodków politycznych pretendowało do władzy. Kraj był zniszczony i wygłodzony, a do tego granice trzeba było wytyczać drogą zbrojną, pomimo tego, że właściwie nie było jednolitej armii. Brakowało aparatu administracyjnego, który przestawiłby życie gospodarcze i społeczno-polityczne na pracę pokojową. Nic dziwnego, że polska inteligencja miała w tym przypadku do odegrania istotną rolę, a funkcjonowanie państwa zależało przede wszystkim od liczebności i jakości kadr, jakimi mogło dysponować.

Należy zaznaczyć, że z pewnością proces budowy państwa oraz tworzenie jego aparatu zaktywizowały do działania dość szerokie grono fachowców i działaczy wśród inteligencji, którzy wykonywali tytaniczną wręcz pracę, w trudnych przecież warunkach dwudziestolecia międzywojennego, co było widoczne w odbudowie i organizacji nowego państwa polskiego oraz zapewnieniu warunków do pokojowej egzystencji.

Słowa kluczowe: inteligencja, ,państwowa służba cywilna”, Druga Rzeczpospolita.

\section{Inteligencja, czyli kto?}

I nteligencja polska ukształtowana na przestrzeni XIX w. miała spełniać różnorodne zadania. Jednym z najważniejszych była „służba państwowa”, realizowana między innymi poprzez pracę na państwowych etatach. Pierwszy raz miało to nastąpić wyraźnie w czasach Księstwa Warszawskiego. Maciej Janowski pisał na ten temat:

* Uniwersytet Marii Curie Skłodowskiej w Lublinie, Wydział Humanistyczny, Zakład Historii Najnowszej, email: robert.litwinski@poczta.umcs.lublin.pl. 
[...] Księstwo Warszawskie miało być państwem rzadzonym przez fachowa biurokracje - nie zaborcza, lecz rodzima. Biurokracji tej jeszcze nie było, bo i skad? Trzeba ja byto dopiero stworzyć. Także w Księstwie po raz pierwszy mamy do czynienia z urzędami centralnymi, zbudowanymi w oparciu o zasadę zarzadu jednoosobowego, a nie kolegialnego ${ }^{1}$.

Możemy w tym miejscu zaznaczyć, że w 1918 r. mieliśmy sytuację bardzo podobną i nie zmieniał ogólnej oceny fakt, że niektóre kadry dla polskiej administracji były przygotowywane jeszcze podczas Wielkiej Wojny.

To właśnie w czasach Księstwa Warszawskiego prawodawcy dostrzegli istnienie zawodów umysłowych jako osobnej kategorii, co nie było takie oczywiste, ponieważ niemal powszechnie operowano jeszcze kategoriami stanowymi. $\mathrm{Z}$ tego też względu niezmiernie istotne było to, czy reprezentowano stan szlachecki, mieszczański czy duchowny, a nie to, „czy ktoś pisze książki, gospodaruje na roli czy piastuje urząd"2. Słusznie pisał dalej M. Janowski, że:

zawody umysłowe $w$ Księstwie stały się już częścią oficjalnie uznanej rzeczywistości spotecznej, a państwo zaczęło tworzyć popyt na inteligencję tym bardziej, że urzędnikiem mogła zostać osoba odpowiednio przygotowana (wyksztatcona), która zdała stosowny egzamin. Urzędy honorowe miaty odejść więc $w$ zapomnienie, a powstać miała profesjonalna stużba3.

Były to co prawda właściwe założenia, ale ich realizacja odbiegała już od tej idei, szczególnie po upadku Księstwa i kolejnych dziewiętnastowiecznych przeobrażeniach społeczno-politycznych na ziemiach polskich. Niemniej można tutaj dostrzec genezę dwudziestowiecznej koncepcji korpusu służby cywilnej powołanego do życia w II Rzeczypospolitej.

Pojęcie ,inteligencja” charakteryzowało się znaczną pojemnością i płynnością granic ${ }^{4}$. Zgodzić się należy ze stwierdzeniem, że warstwa ta była pewnym konglomeratem, składającym się w XIX w. z elementów pochodzących z róż-

${ }^{1}$ M. Janowski, Narodziny inteligencji 1750-1831, Warszawa 2008, s. 132.

2 Ibidem.

3 Ibidem, s. 134-135.

4 Jak stwierdza J. Żarnowski: „Inteligencja ukształtowała się w Polsce, według najczęstszej wśród historyków opinii, w XIX wieku, a w każdym razie w nowy, XX wiek wkroczyła jako uformowana już i powszechnie uznana warstwa społeczna”, a „Polska należy do krajów, w których inteligencja odgrywała w XIX i XX wieku samodzielną rolę i stanowiła odrębną formację w społeczeństwie, choć jej granice nigdy nie były ściśle określone [...]. Inteligencja zaczęła się tworzyć, w postaci różnych kategorii zawodowych, już w czasach stanisławowskich, a następnie w okresie Księstwa Warszawskiego. Dopiero jednak w połowie XIX stulecia ukształtowała się jako samodzielna warstwa i uzyskała świadomość swej odrębności. Początkowo odrębność ta zaznaczyła się w większych ośrodkach: w Warszawie, Poznaniu, Krakowie; później upowszechniła się. Pod koniec XIX wieku inteligencja stała się warstwą w praktyce decydującą o sprawach narodowych i kulturalnych". Zob. J. Żarnowski, Inteligencja, [w:] W. Mędrzecki, Sz. Rudnicki, J. Żarnowski, Społeczeństwo polskie w XX wieku, Warszawa 2003, s. 74. 
nych środowisk społecznych, pretendujących do celów wyższych, do bycia elitą. Nie aspirowali oni jeszcze do włączenia ich do inteligencji jako takiej. Nie mogli bowiem wówczas wiedzieć (przynajmniej do połowy XIX w.), że i tak określać się ich będzie tym mianem. Jak stwierdza Janusz Żarnowski:

\begin{abstract}
Jedne [środowiska] zwiąane były ściśle ze stanem szlacheckim, jak np. prawnicy, oficerowie, inne raczej z mieszczaństwem, często niepolskim, jak lekarze, częściowo artyści: muzycy, malarze, architekci, śpiewacy. Zawody umystowe, których przedstawiciele utrzymywali się z pracy najemnej, nawet na ustugach państwa, nie cieszyły się w oczach arystokracji wysokim prestizem. Jednakże liczni synowie biednej szlachty wyczekiwali na posady państwowe i inne tego typu zatrudnienie. [...] Po uwłaszczeniu chłopów w Królestwie Polskim i po podobnych reformach na innych ziemiach polskich stosunkowo znaczna liczba dawnych posiadaczy ziemskich zaczęła szukać pracy w zawodach inteligenckich. Postszlachecki charakter inteligencji polskiej uległ wówczas wzmocnieniu. Wkrótce jednak pojawili się także inteligenci pochodzący spośród drobnomieszczaństwa i chłopów ${ }^{5}$.
\end{abstract}

Po odzyskaniu niepodległości sprawy pochodzenia poszczególnych zawodów ulegały zatarciu.

W „Dzienniku Literackim” z 1861 r. czytamy m.in.:

Cóż więc jest ta inteligencja, i co ona ma oznaczać? Śmieszne to dziś pytanie, może kto pomyśleć, gdy każdy prawie człowiek czyta jedno pismo publiczne, zajmuje myśl swoja choćby odrobinkę sprawami publicznemi. Otóż właśnie w tym czytaniu i zajmowaniu się, znalazłem jeden powód więcej, przejrzenia się bliżej w znaczeniu polskiem inteligencji. Każdy żak wie, że inteligerre zowie się po polsku rozumieć, ale co rozumieć w tem sęk. Jakiego więc rozumienia wymaga od inteligencji nasze społeczeństwo, aby ją tem mianem nazwać mogło [...]. A czy nie wypadnie tylko z wywodu tego, że inteligencja oznacza u nas dzisiaj to samo, co nasze dawne w mnogiej liczbie «dobrze myślacy» [...]. Cała różnica, jeżeli już komu gwaltem chodzi o dośledzenie różnicy, zależy na tem, że w naszem dawnem "dobrze myślacy», była część procesu umysłowego wzięta w całość, myślenie za rozumienie, zaś w nowożytnem stowie «inteligencja», mowa jest wprost o samem rozumieniu, jako wplywie myślenia.

Oczywiście w tym przypadku istotną rolę odgrywały narodowe tradycje i przekonania ${ }^{6}$. Z kolei Aleksander Świętochowski twierdził, że inteligencja „to jakby zestawienie ludzi na zasadzie cenzusu intelektualnego", do którego dochodziła ich codzienna działalność, tj. praca umysłowa ${ }^{7}$.

W dwudziestoleciu międzywojennym nie określano dokładnie, kto właściwie do tej inteligencji należał, co w sposób obrazowy tak ujął J. Żarnowski:

\footnotetext{
5 Ibidem, s. 74-75.

${ }^{6}$ C.Ch., O inteligencji w znaczeniu polskim, „Dziennik Literacki” 1861, nr 100, s. 802-804.

${ }^{7}$ Cyt. za: T. Stegner, ,Postępowa demokracja” a inteligencja, [w:] Inteligencja polska XIX i XX wieku. Studia, t. 4, pod red. R. Czepulis-Rastenis, Warszawa 1985, s. 281.
} 
Przynależność bowiem do tej warstwy społecznej określano swoiście: bez watpienia inteligentem byt ten, kogo przyjmowano w domach inteligenckich, kto wchodzit do mieszczańskich domów przez drzwi frontowe, a nie przez kuchenne, przeznaczone dla stużby, handlarzy, dozorcy domu itp.; ten, kogo można było poprosić na imieniny i za kogo można było wydać córkę bez obawy mezaliansu. Człowiek taki zajmowat się oczywiście praca umystowa, nigdy fizyczna ${ }^{8}$.

Można w tym miejscu jednak zadać pytanie, czy rzeczywiście mezaliansem nie było zamążpójście ziemianki za biednego urzędnika, który przecież szczycił się mianem ,inteligenta”? Wydaje się, że w tym przypadku byłaby to kwestia dyskusyjna.

Niebagatelny był także fakt zróżnicowania państwa pod względem rozwoju społecznego, politycznego i gospodarczego. Inaczej należałoby bowiem zdefiniować przedstawicieli inteligencji w stolicy, a inaczej na obszarach prowincjonalnych. Poza tym nie bez znaczenia był brak samodzielności politycznej, a także antypolska, a więc przede wszystkim antyinteligencka polityka władz zaborczych. Utrudnianie Polakom zdobywania wykształcenia, czy też niedopuszczanie w zaborze rosyjskim i pruskim do służby państwowej powodowało, że pewne kategorie zawodowe pojawiły się tylko w postaci zalążkowej albo rozwinęły się jedynie w Galicji, gdzie Polacy mogli od lat 70. XIX w. uczestniczyć w działalności politycznej i pracach administracyjnych, a także bez przeszkód pracować naukowo i brać udział w życiu uniwersyteckim. Ten element będzie odgrywał istotną rolę w rozwoju politycznym, gospodarczym i kulturalnym Polski po 1918 r. ${ }^{9}$ Włodzimierz Mędrzecki na przykład zalicza do interesującej nas warstwy na terenie województwa wołyńskiego kręgi urzędnicze, przedstawicieli wolnych zawodów, przedstawicieli środowisk twórczych, nauczycieli, oficerów Wojska Polskiego, Policji Państwowej i Korpusu Ochrony Pogranicza, duchownych, ale także ziemian, kupców, przedsiębiorców i osadników wojskowych ${ }^{10}$.

\section{W II Rzeczypospolitej}

Euforii z odzyskanej niepodległości towarzyszyła troska o odpowiednie zorganizowanie państwa, które nie miało nawet ogólnopolskiego rządu, a kilka ośrodków politycznych pretendowało do władzy. Kraj był zniszczony i wygłodzony, a do tego granice trzeba było wytyczać drogą zbrojną, pomimo faktu, że właściwie nie było jednolitej armii. Brakowało aparatu administracyjnego, który przestawiłby życie gospodarcze i społeczno-polityczne na pracę pokojową. Nic dziwnego, że

\footnotetext{
8 J. Żarnowski, O inteligencji polskiej lat międzywojennych, Warszawa 1965, s. 8.

${ }^{9}$ Idem, Inteligencja..., s. 77-78.

${ }^{10}$ W. Mędrzecki, Inteligencja polska na Wołyniu w okresie międzywojennym, Warszawa 2005, s. $10-11$.
} 
polska inteligencja miała $\mathrm{w}$ tym przypadku do odegrania istotną rolę, a funkcjonowanie państwa zależało przede wszystkim od liczebności i jakości kadr, jakimi mogło dysponować. Zorganizowania od podstaw wymagały przede wszystkim:

1) administracja centralna;

2) terytorialna administracja rządowa (wojewódzka i powiatowa);

3) administracja specjalna (wojskowa, skarbowa, celna, sądowa, pocztowa, kolejowa, oświatowa, archiwów państwowych, górnicza, miar i narzędzi mierniczych, żeglugi morskiej, dróg wodnych, lasów państwowych), szkolnictwo, związki wyznaniowe, administracja gospodarcza);

4) samorząd terytorialny;

5) samorząd gospodarczy i zawodowy.

Tak więc, zapotrzebowanie na kadry stojące na odpowiednio wysokim poziomie było olbrzymie, a specjalistów brakowało. Nie zmieniły tego powroty naukowców z zagranicy, bo w niektórych dzielnicach brakowało przede wszystkim urzędników szczebla średniego. Najlepszym przykładem była dawna dzielnica pruska. Na 4500 dotychczasowych urzędników było tylko 40 osób narodowości polskiej i to na stanowiskach urzędników niższych. Polaków nie dopuszczano także do pracy w kolejnictwie, szkolnictwie i urzędach pocztowych ${ }^{11}$. Pomimo prac zmierzających do spolszczenia administracji i przejmowania stanowisk kierowniczych, pozostawiano nadal niemieckich fachowców: sędziów, urzędników, nauczycieli, pracowników poczt i kolei, przy czym dokonywano tego na podstawie stosownych porozumień pomiędzy rządami Polski i Niemiec ${ }^{12}$.

Co prawda, pomyślnym czynnikiem okazało się przygotowanie odpowiednich kadr na terenie Galicji, bo teraz mogły one zasilać inne części kraju, ale odbywało się to bardzo często w atmosferze tarć i wzajemnych animozji. Dotychczasowe podziały dzielnicowe odciskały bowiem nadal swe piętno i tkwiły w umysłach społeczeństwa. Tak pisał na ten temat J. Żarnowski:

Nie tylko wychowani w twardej pruskiej szkole Poznańczycy z niechęciq odnosili się do przybyszów z Królestwa i Galicji, uważając ich za niegospodarnych i przesiąkniętych wptywami rosyjskimi, ale i sami «Galileusze» z tytułami doktorów i radców z góry patrzyli na «warszawistów z domowym wyksztatceniem» i przedstawicieli innych zaborów. Królewiacy też nie zawsze odnosili się przychylnie do «austriackich hofratów»"

${ }^{11}$ A. Gulczyński, Ministerstwo bytej Dzielnicy Pruskiej (1919-1922), Poznań 1995, s. 115.

12 Ibidem, s. 117.

13 J. Żarnowski, O inteligencji polskiej..., s. 57-58. 
Jak słusznie zaznacza Magdalena Micińska:

Wyksztatceni i zaangażowani w życie publiczne Polacy z kilku różnych dzielnic zaborowych wkraczali w niepodległość z różnym zasobem doświadczeń i aspiracji. Przede wszystkim niewspótmierna była praktyka życia parlamentarnego, a także samorządowego, jaka - w konsekwencji polityki uprawianej przez mocarstwa zaborcze - stała się udziałem polskich inteligentów trzech zaborów. W obu sferach najlepiej potrafili poruszać się Galicjanie. W obu także najmniejsze doświadczenie wynieśli z epoki rozbiorowej Polacy z zaboru rosyjskiego. Zarazem kłóciło się to z przekonaniem inteligencji bytego Królestwa, a zwłaszcza Warszawy (po raz pierwszy od przeszło wieku pretendujacej do pozycji metropolii narodowej!), że to ona właśnie - ze względu na swoją liczebność, wewnętrzna jedność, świadomość, nowoczesność i zasługi niepodległościowe - powinna objąć najważniejsze funkcje w całym państwie. Podobne aspiracje byty udziałem inteligencji Krakowa czy Lwowa, przeświadczonej, że wytacznie ona - dzięki wyrobieniu otrzymanemu w autonomicznej Galicji-posiada kwalifikacje wystarczające do rządzenia krajem. Ambicje te, częstokroć wyrażane w sposób bezpodstawnie arogancki, w oczywisty sposób godzity w regionalna dumę Ślazaków, Wielkopolan, Wolyniaków czy mieszkańców Wilna. Narosłe po 1918 roku urazy przetrwały przez caty okres międzywojenny ${ }^{14}$.

Były one widoczne niemal we wszystkich sferach działalności państwa, a pamiętać należy o autonomii województwa śląskiego, którego rodowici mieszkańcy byli bardzo czuli na punkcie swych praw. Zapominano przy tym, że to nie miejsce urodzenia, ale wychowanie i charakter kształtowały model konkretnych zachowań.

Odzyskanie niepodległości stworzyło więc odpowiednie warunki do podejmowania rozwiązań instytucjonalnych. Konieczność zorganizowania administracji, prowadzenie polityki gospodarczej i organizacji systemu edukacji były tutaj najlepszym przykładem, a podwaliny pod nie kładli ludzie ukształtowani w warunkach niewoli. Gdy porównamy prace prowadzone w ramach Rady Regencyjnej chociażby w sferze administracji i bezpieczeństwa publicznego, to zobaczymy jak wiele rozwiązań zadziałało w pierwszych miesiącach niepodległości.

Oczywiście niezmiernie istotnym elementem był dobór odpowiednich pod względem wykształcenia kadr. Co prawda większych problemów nie było w administracji szczebla centralnego. Na przykład w przypadku Ministerstwa Wyznań Religijnych i Oświecenia Publicznego ministrowie, podsekretarze stanu, dyrektorzy departamentów, szefowie sekcji i naczelnicy wydziałów byli dobrze wykształceni. Pracowali na tych stanowiskach profesorowie, często fachowcy i eksperci w swoich dziedzinach ${ }^{15}$. Gorzej było na niższych etatach. We wszystkich resortach panował wręcz, jak pisze Wojciech Witkowski, „niedobór osób

${ }^{14}$ M. Micińska, Inteligencja na rozdrożach 1864-1918, Warszawa 2008, s. 193-194.

15 P.A. Leszczyński, Centralna administracja wyznaniowa II RP. Ministerstwo Wyznań Religijnych i Oświecenia Publicznego, Warszawa 2006, s. 222-223. 
z wyższymi kwalifikacjami zawodowymi i odpowiednim doświadczeniem. W 1923 r. w administracji było zatrudnionych ok. 120 tys. osób, spośród których zaledwie 15 tys. legitymowało się wyższym wykształceniem"16.

Dochodziło do tego ogromne zapotrzebowanie (zróżnicowane co prawda w poszczególnych dzielnicach kraju) na przedstawicieli wolnych zawodów (lekarzy, adwokatów itd.) i wszelkiego rodzaju pracowników umysłowych na stanowiskach kierowniczych i specjalistycznych (wyżsi i średni urzędnicy państwowi, nauczyciele, inżynierowie, duchowni, oficerowie służb mundurowych, poczynając od wojska, a kończąc chociażby na policji i formacjach ochrony granic) ${ }^{17}$. To właśnie posiadane kompetencje i umiejętności miały być elementami decydującymi o obsadzie etatów. Praktyka jednak wyglądała nieco odmiennie i nierzadko najważniejsze były dotychczasowe „zasługi” niepodległościowe.

Co prawda na plan pierwszy wysuwały się zagadnienia polityczne, tj. tworzenie struktur państwa i sprawnych organów władzy ${ }^{18}$, ale nie mniej ważne były pozostałe domeny życia odrodzonej Rzeczypospolitej, chociażby takie jak: aprowizacja, higiena i stan zdrowia, przemysł, nauka, kultura itp. Trudno na przykład w tym miejscu pominąć chociażby ogromne zapotrzebowanie na inteligencję z wykształceniem technicznym, zajmującą się uruchamianiem przedsiębiorstw i całych gałęzi produkcji ważnych dla gospodarki i obronności kraju. Dzięki jej aktywności szybko opanowano między innymi produkcję różnorodnego sprzętu wojskowego oraz środków transportu i łączności, co w pewnym sensie pozwalało na skracanie dystansu do europejskiego poziomu technicznego ${ }^{19}$. Przyznać jednak należy, że w wielu aspektach nie udało się nawet zbliżyć do średniej obowiązującej w państwach zachodnich. Na przykład z lektury „Kuriera Porannego" z 1937 r. dowiadujemy się, że Polska miała 50 razy mniej samochodów niż Niemcy (wg stanu na 1 I 1937 r.) i zdecydowanie mniej utwardzonych dróg, które i tak były w fatalnym stanie ${ }^{20}$.

Definiując zadania międzywojennej inteligencji, należałoby odwołać się do opinii współczesnych, nawiązujących do ,,inteligenckiej misji i odpowiedzialności za nadawanie kształtu nowej polskiej rzeczywistości”"21. Zdzisław Dębicki nawoływał na przykład, aby inteligencja podołała tradycyjnie przypisanej jej roli przewodnika i okazała się prawdziwym kierownikiem społeczeństwa. Poruszał

16 W. Witkowski, Historia administracji w Polsce 1764-1989, Warszawa 2007, s. 372.

17 I. Ihnatowicz, A. Mączak, B. Zientara, J. Żarnowski, Społeczeństwo polskie od X do XX wieku, Warszawa 2005, s. 627.

18 P. Górski, Między inteligencka tradycją a menadżeryzmem. Studium kształtowania środowiska naukowej organizacji, jego ideologii i działań organizatorskich $w$ Polsce międzywojennej, Kraków 2005, s. 66.

19 J. Żarnowski, Inteligencja..., s. 80.

20 W.R., Autostrady a nasze potrzeby wojenne, „Kurier Poranny” 1937, nr 275, s. 3-4.

21 P. Górski, op. cit., s. 66. 
przy tym problem modernizacji i dostosowywania społeczeństwa do nowych warunków, chociażby poprzez profesjonalizację i doskonalenie kadr. Pisał między innymi:

Polska inteligencja techniczna musi więc przemysłowi krajowemu dostarczyć przede wszystkim organizatorów, zdolnych do tworzenia nowych przedsiębiorstw, do zrywania $z$ dotychczasowa rutyna, do głębokiego wnikania w poszczególne dziedziny życia gospodarczego kraju i zaspokajania potrzeb tego życia na drogach rodzimego wysiłku ${ }^{22}$.

\section{Poza tym nowoczesne państwo musiało do sprawowania władzy powołać}

caty szereg sił inteligentnych, które $w$ zbiorowym aparacie rzadzenia spełniatyby poszczególne funkcje możliwie najdokładniej, najlepiej, najuczciwiej, nie tylko z wykluczeniem jakichkolwiek nadużyć, ale ze stałem obywatelskim dążeniem do tego, aby te nadużycia ze strony mniej uświadomionych obywateli ukrócić, nieporzadkom i wstrzaśnieniom społecznym zapobiec, grożace niebezpieczeństwa przewidzieć, ład i porzadek utrzymać, a w ponoszeniu ciężarów i powinności państwowych przez ogół ustalić lojalny tego ogółu stosunek do siebie, nie zezwalajacy na obtude, fatsz i podstep, na ukrywanie rzeczywistych dochodów przed okiem urzędów podatkowych, na uchylanie się od stużby wojskowej itp. ${ }^{23}$.

Tak więc poważne zadania czekały na inteligencję, która powinna zostać zobligowana do dostarczenia takich kandydatów do zarządzania państwem we wszelkich dziedzinach,

którzy by nie tylko wszelki urząd polski reprezentowali godnie i obowiazki swoje spetniali bez zarzutu, ale którzy jednocześnie, jako żywioł wyksztatcony i kulturalny, rozprowadzony po całym kraju, mogliby krzewić wyższa kulturę w prowincjonalnych ośrodkach naszego życia, stale cierpiących na niedobór twórczych sit inteligentnych, z drugiej strony, mając kontakt z życiem prowincjonalnym, informowaliby wladze centralna o tym życiu tak, aby jego potrzeby zaspokajane byty nie wedlug schematów teoretycznych, ale w petnym poczuciu rzeczywistości $i^{24}$.

Nie bez znaczenia było przy tym zapewnienie odpowiedniego uposażenia tej grupie społecznej. Stefan Żeromski, nawołując do tworzenia związków i stowarzyszeń urzędniczych, tak pisał w maju 1919 r.:

Przeciętna, uczciwa masa inteligencyi zawodowej bytowaniem swem przypomina los guwernantki $w$ szlacheckim dworze. Należy niby do "państwa», a sympatyami i miłościa tradycyjna «siermięgi» związana jest wciąz jeszcze z «chatą». Dwakroć biedniejsza od każdej z pokojówek, nie chce się dać zepchnać do poziomu stużby, do kategorji zwykłego proletariatu, stawia się i pnie w górę, broni swych praw do zasiadania przy pańskim stole $[\ldots]^{25}$.

${ }^{22}$ Z. Dębicki, Kryzys inteligencji polskiej, Warszawa-Lublin-Lódź-Kraków 1918, s. 165.

${ }^{23}$ Ibidem, s. 226-227.

${ }^{24}$ Ibidem, s. 233-234.

25 S. Żeromski, Organizacya inteligencyi zawodowej, Warszawa-Kraków 1919, s. 8. 
I dalej: Cóż ma czynić ze soba ta nieszczęsna społeczne guwernantka, ażeby w tych okrutnych czasach mieć się przede wszystkiem w co odziać, co jeść i nie skapieć z nędzy, a przecie znaleźć i dla siebie także miejsce pod stońcem? Prosta rada: porozumieć się ze wszystkiemi innemi guwernantkami w kraju i wytworzyć jakiś zespót, któryby o losie swoim, jako zbiorowego ciała pod każdym względem pomyślat. Lecz czy możliwe jest zrzeszenie się inteligencyi? Jest to niewatpliwie sprawa trudna i natrafiajaca na przeszkody przedewszystkiem ze strony potężnych partii, które nie zechca pozbyć się „swych” inteligentów, swych wołów roboczych, wypracowujacych im programy i umożliwiajacych wykonanie owych programów, - a powtóre - ze strony samychże inteligentów, powszczepianych dziś w najrozmaitsze zrzeszenia i majacych tam już swe idejowe materialne posady ${ }^{26}$.

To samoorganizowanie się inteligencji zawodowej miało w rozumieniu Żeromskiego doprowadzić do powstania idealnego modelu. Uważał on bowiem, że inteligencja zorganizowana w związki zawodowe będzie w stanie dbać nie tylko o wynagrodzenie każdego ze swych członków, ale

Znając doktadnie i nawskroś wszystko, cokolwiek dzieje się w biurach, pracowniach, na katedrach, przy stolikach i za przepierzeniami istotnej pracy, inteligencya sparalizuje absolutnie system protekcyi nieuzasadnionej, nepotyzmu, wysforowywania koczkodanów partyjnych na stanowiska kierownicze, uniemożliwi otwieranie kluczem partyjnym wysokich drzwi rzadu przez notorycznych mydlków i spryciarzy, przekupstwo dla otrzymania urzędów wyższych, karierowiczostwo, wszelakie nadużycie i niesprawiedliwość w awansie ${ }^{27}$.

Podkreślić wypada, że nie traktował on tej warstwy jednolicie. Krytycznie wypowiadał się o „wyższej” inteligencji. Uważał mianowicie, że:

Nie warto bytoby organizować wszelkiej inteligencyi, jaka w kraju być może, gdyż sa pewnie przedstawiciele wysokiej nawet inteligencyi w sferze paskarzy, magnaterii, dorobkiewiczów, wyzyskiwaczów właśnie pracy, którzy takiego organizowania się wcale nie potrzebuja i nie pragna. Co wszyscy sprzedaliby nie tylko swe sumienie, nie tylko Polskę, jak to widać z ich postępowania i z procesów, które im raz wraz władza wytacza, - ale cały rodzaj ludzki dla zabezpieczenia swych dóbr, majątków, fortun, zbiorów, dla oszczędzenia sobie przykrości, wskutek niskiej i ślepej czołobitności względem każdej sity ${ }^{28}$.

Siłę napędową rozwoju widział więc w kręgach inteligencji pracującej, która działając w sposób zorganizowany, była - jego zdaniem - w stanie przeciwstawić się wszelkim nadużyciom i, poprzez wypracowanie odpowiednich standardów postępowania w sferze publicznej, potrafiła

${ }^{26}$ Ibidem, s. 18. Udało się jednak zorganizować w latach 1924-1925 Polską Konfederację Pracowników Umysłowych i Centralną Organizację Związków Zawodowych Pracowników Umysłowych.

${ }^{27}$ Ibidem, s. 22-23.

28 Ibidem, s. 27. 
pokazać w sposób naukowy, dowodowy, eksperymentalny wszelkie frantowstwo i karyerowiczowstwo, matactwo i blage polityków, wodzów partii $i$ wszelakich oszustów, żyjacych $z$ reprezentacyi biedy, zdażajacych po zgiętych karkach do krzeset władzy. Ona, majaca w swem tonie wszystkich pracowników, od męża wysokiej nauki, wykładającego na katedrze uniwersyteckiej, do skromnego siewcy oświaty w szkole ludowej, od głębokiego ekonomisty, czy socyologa, do zarzadcy, czy praktykanta, w prywatnym rolnym majatku, od znakomitego adwokata, który bierze na siebie obronę życia klienta przed sadem, do pracownika za okienkiem pocztowem $w$ dalekiem miasteczku, od świetnego talentu publicysty do cichego wspótpracownika w prowincyonalnem piśmie, - obejmując wszystkich ludzi, których życie skierowato nie na droge pracy fizycznej, lecz pracy umystowej, ona to, inteligencya, stanie się sama siła rzeczy czynnikiem także politycznym, ukaże się na widowni i zacznie grać role wybitna. Ona jedna, inteligencya zorganizowana, siostra rodzona pracy fizycznej, może tej drugiej wyjaśnić istotna prawdę, rozwiktać zgmatwane $i$ wrzaskliwie głoszone tezy prowodyrów partyjnych, wskazać istotna drogę, po której kroczyć należy. Ona tylko czynić to będzie bezinteresownie, gdyż nie będzie polowała na mandat, ani nie będzie na głoszeniu zasad zbijała majątku. Nie wyshugując sie już partyom i siłom, wrogim ludowi, sama przez organizacyę uniezależniona i sama będąc ludem, może w sposób śmiały, decydujacy i niezłomny osiagnać prawdę $w$ dziedzinie spotecznej $[\ldots]^{29}$.

Zaiste pobożne to były życzenia. Prawie tak samo jak wizja szklanych domów. I podobnie jak one nierealne. Żeromski z nimi jednak zapewne się utożsamiał, skoro J. Lechoń pisał o nim:

[...] byt dzieckiem pokolenia idealistów, któremu równe - między nami powiedzieć to można - nie pojawiło się nigdzie poza naszym krajem. Ludzie ci żyli dla innych, dla biednych, dla wydziedziczonych, dla spraw trudnych, nieraz straconych, dla przyszłości, której najczęściej nie widzieli, ginac $w$ walce z losem, a nieraz i na sznurach szubienic. Nie żadali oni naprawde niczego dla siebie od losu i od ludzi, nie wygtaszali dobrze płatnych odczytów o przyszłości świata, żadne pisma nie czynity z nimi wywiadów i nie umieszczaty ich fotografii. Byli to ludzie bezdomni, bo sami wyrzekali się domu i szli z chlebem, ze świattem wiedzy, z nauka wolności - na poddasza, do suteren, do wiejskich chatup. Byli wśród nich studenci i wiejskie nauczycielki, panny, które porzucily swoje zasobne domy, uczeni, którzy wzgardzili odkrywcza sława, aby nauczać abecadła, byli żotnierze rewolucji i ci, co żyli, aby wspierać skazanych i umierajacych ${ }^{30}$.

Oto zadania bezinteresownego inteligenta, który miał być nauczycielem i drogowskazem dla tych, którzy stali „,niżej” od niego ${ }^{31}$.

Ale właśnie ci inteligenci byli predestynowani do realizacji zadań, o których wspominano uprzednio. Przecież już w XIX w. wchodzili w skład kierownictwa przeważającej liczby ugrupowań politycznych. Podobnie było w przypadku organizacji społecznych. Nic też dziwnego, że ich rola wzrosła po listopadzie 1918 r. Warto w tym miejscu zaznaczyć, że według danych z kwietnia 1919 r.

\footnotetext{
${ }^{29}$ Ibidem, s. 28-29.

30 J. Lechoń, Portrety ludzi i zdarzeń, oprac. P. Kądziela, Warszawa 1997, s. 177-178.

${ }^{31}$ S. Żeromski, op. cit., s. 34.
} 
w Sejmie Ustawodawczym przedstawiciele środowisk inteligenckich zajmowali 149 na 348 miejsc, co stanowiło 42\% ogólnego stanu posłów. Tak znaczny odsetek ludzi wywodzących się z tej sfery nie był czymś nadzwyczajnym, wszak byli wśród nich - o czym już wspomniano - przywódcy różnych partii politycznych, a także liczni eksperci ${ }^{32}$. W sejmie wybranym w 1922 r. przedstawiciele inteligencji stanowili około $2 / 3$ ogółu posłów. Podobnie było w senacie ${ }^{33}$. W kolejnych kadencjach ten odsetek był także znaczny, ale musimy pamiętać, że po $1926 \mathrm{r}$. parlament przestawał być centrum decyzyjnym życia politycznego.

Wypada także pamiętać, że to głównie inteligencja w latach Wielkiej Wojny prowadziła prace studyjne nad zasadami organizowania administracji w niepodległym państwie, przede wszystkim z niej rekrutowała się elita władzy, która zaczęła w sposób zorganizowany tworzyć się podczas Wielkiej Wojny (za rządów Rady Regencyjnej), ale wykrystalizowała się i umacniała już po odzyskaniu niepodległości. Zdaniem Bohdana Cywińskiego, po odzyskaniu niepodległości

\begin{abstract}
Zadania spoleczne inteligencji zmieniaty się w sposób najbardziej zasadniczy $i$ najbardziej widoczny: po póttorawiekowej niewoli stanąt przed nia problem zbudowania nowego, dwudziestowiecznego aparatu państwowego i operowania nim w sytuacji wewnętrznej i zewnętrznej, której dramatyczność niełatwo już dziś sobie w petni uświadomic ${ }^{34}$.
\end{abstract}

Przyznać przy tym należy, że udało się to zrealizować w znacznej mierze dzięki dużemu zaangażowaniu oraz dokonującej się profesjonalizacji administracji centralnej, terytorialnej administracji rządowej, administracji specjalnej, samorządu terytorialnego, gospodarczego i zawodowego ${ }^{35}$. Na przykład już w 1922 r. wydano przepisy o korpusie państwowej służby cywilnej, zwanej pragmatyką służbową. Dzieliły one wszystkich funkcjonariuszy tej służby na urzędników i niższych funkcjonariuszy państwowych ${ }^{36}$. Ustawa ta nie dotyczyła sędziów, prokuratorów i aplikantów sądowych, nauczycieli szkół i profesorów akademickich, pracowników kolei, poczt, telegrafów i telefonów, funkcjonariuszy policji, straży granicznej, więziennej i monopoli państwowych oraz kontroli państwowej. Te kategorie zawodowe miały odrębne pragmatyki. Jeżeli dodamy do tego ogromną liczbę uchwalonych aktów prawnych służących scalaniu rozbitego przez 123 lata państwa i normujących wszelkie sfery jego działalności, to zdamy sobie sprawę ze znacznego wysiłku legislacyjnego inteligencji II Rzeczypospolitej.

${ }^{32}$ A. Ajnenkiel, Historia Sejmu Polskiego, t. 2, cz. 2, II Rzeczpospolita, Warszawa 1989, s. 28.

${ }^{33}$ Ibidem, s. 89.

${ }^{34}$ B. Cywiński, Rodowody niepokornych, Warszawa 1971, s. 110.

${ }^{35} \mathrm{Na}$ temat profesjonalizacji administracji państwowej zob. m.in.: P. Górski, Profesjonalizacja administracji państwowej w Polsce 1918-1939. Uwarunkowania społeczne i kulturowe, Kraków 2011, ss. 290.

${ }^{36}$ Ustawa z dnia 17 lutego 1922 r. o państwowej stużbie cywilnej, „Dziennik Ustaw Rzeczypospolitej Polskiej" 1922, nr 21, poz. 164; W. Witkowski, op. cit., s. 371. 
Z całą pewnością inteligencja zaczynała się coraz bardziej „wyodrębniać spośród ogółu «pracowników umysłowych», tj. niemanualnych", których szeregi szybko rosły ze względu na rozwój państwa i towarzyszący temu rozrost biurokracji ${ }^{37}$. Zgodzić się należy z panującym w literaturze przedmiotu stwierdzeniem, że warstwa inteligencka stawała się coraz liczniejsza i razem z rodzinami stanowiła już poważną grupę, liczącą w połowie dwudziestolecia międzywojennego ponad półtora miliona osób. Poza tym pojęcie ,inteligencji” zaczęło się zacieśniać bardziej do kategorii specjalistów wszelkiego rodzaju (urzędnicy państwowi i samorządowi, sędziowie i prokuratorzy, adwokaci, nauczyciele i naukowcy, oficerowie, duchowieństwo, lekarze, aptekarze, inżynierowie, technicy, literaci, aktorzy, dziennikarze itp.), przy czym trzonem tej grupy byli coraz liczniejsi ludzie posiadający dyplomy szkół wyższych. Z pewnością zabrzmi to jak truizm, jeżeli podkreślimy, że stanowili oni najwyżej ułamek procenta, drobną cząstkę społeczeństwa, w którym przeważali nadal chłopi, ale wraz z rozwojem szkolnictwa wszystkich typów, a przede wszystkim wyższego, ich liczba rosła $^{38}$. W $1921 \mathrm{r}$. inteligencja wraz z pracownikami umysłowymi stanowiła 5,1\% społeczeństwa II Rzeczypospolitej, w 1931 r. - 5,6\%, a w 1938 r. - 5,7\% ${ }^{39}$.

Przy wzroście liczebnym niezmiernie ważne było także doskonalenie zawodowe i profesjonalizacja (wręcz menadżeryzm) przedstawicieli tej grupy. Pamiętać bowiem należy, że przeobrażenia gospodarcze sprzyjały tworzeniu miejsc pracy dla pracowników umysłowych chociażby w przemyśle, potrzebującym wykształconej kadry kierowniczej (nazwijmy ją inteligencją techniczną). Co prawda intensyfikacja tych przemian przypadła na lata 30 . XX w., w dobie licznych inwestycji przeznaczonych dla ludności cywilnej i wojska, ale przecież te potrzeby były zauważalne od samego początku istnienia II Rzeczypospolitej ${ }^{40}$. Również nowe inicjatywy gospodarcze, takie jak chociażby budowa portu w Gdyni, nowych linii kolejowych, Zakładów Azotowych w Mościskach czy Centralnego Okręgu Przemysłowego - dawały pracę znacznej liczbie pracowników z wykształceniem technicznym.

Jednak zadaniem polskiej inteligencji miała być nie tylko praca zawodowa, ale również aktywna działalność kulturalno-oświatowa oraz społeczna na „rzecz integracji i wzmacniania środowiska polskiego oraz aktywne oddziaływanie na rzecz propagowania polskości wśród obywateli państwa innej niż polska narodowości”. Polski inteligent miał być w tym przypadku „wzorem postawy obywatelskiej”"41. Taka postawa była niezmiernie ważna na terenach o znacznym odsetku ludności niepolskiej.

${ }^{37}$ I. Ihnatowicz, A. Mączak, B. Zientara, J. Żarnowski, op. cit., s. 626.

38 Ibidem.

39 J. Żarnowski, Społeczeństwo Drugiej Rzeczypospolitej 1918-1939, Warszawa 1973, s. 32.

${ }^{40}$ P. Górski, Między ..., s. 50-56. Por. J. Żarnowski, Inteligencja ..., s. 80.

${ }^{41}$ W. Mędrzecki, Inteligencja polska na Wołyniu w okresie międzywojennym, Warszawa 2005, s. 77. 
Nic więc dziwnego, że ogrom zadań czekał na nauczycieli z odpowiednim wykształceniem i profesorów szkół wyższych, tym bardziej, że oni również zostali zmuszeni do migracji po kraju. Okazało się bowiem, że konieczne stało się wsparcie niektórych dzielnic Polski (Wielkopolski, Pomorza i Śląska, ale także Królestwa). Jak podaje J. Żarnowski, na Śląsku jeszcze w 1925 r. było 53\% nauczycieli pochodzących spoza tej dzielnicy ${ }^{42}$. Także część z profesorów zmuszona była do zmiany miejsca zatrudnienia w celu wzmocnienia innych ośrodków akademickich. Na przykład 67 pracowników naukowych Uniwersytetu Jagiellońskiego przybyło do Warszawy zasilając kadry tutejszych uczelni. Naukowcy z Krakowa wsparli również nowo utworzony uniwersytet $\mathrm{w}$ Poznaniu ${ }^{43}$. Inni powracali z zagranicy chcąc pracować na rozwój ojczyzny.

Przyznać należy, że w porównaniu do czasów zaborczych, zdecydowanie wzrosło znaczenie środowiska naukowego. Uznać to należy za konsekwencję dużej aktywności jego przedstawicieli we wszystkich sferach działalności państwa, z piastowaniem urzędu Prezydenta RP włącznie (Gabriel Narutowicz, Ignacy Mościcki). Inni byli z kolei premierami, ministrami, podsekretarzami stanu itp. W Polsce niepodległej przewijało się wiele nazwisk świata nauki, obecnych w życiu politycznym. Wymienić można w tym miejscu chociażby Władysława Jaworskiego (prawnik), Juliana Nowaka (lekarz, rektor Uniwersytetu Jagiellońskiego), który tworzył rząd w 1922 r., Stanisława Estreichera, autora stałego felietonu politycznego w „Czasie”, głównym organie konserwatystów, Kazimierza Bartla - pięciokrotnego premiera czy Leona Kozłowskiego Z pewnością wyróżniającą się postacią był Adam Krzyżanowski (ekonomista) poseł na sejm (z listy Bezpartyjnego Bloku Współpracy z Rządem), generalny referent budżetu, doradca rządu w sprawach finansowych, który karierę polityczną zakończył demonstracyjnym złożeniem mandatu po sprawie brzeskiej. Cieszył się autorytetem moralnym i był bardzo popularną postacią w Polsce. Człowiekiem zajmującym specjalną pozycję był konserwatysta Marian Zdziechowski (filozof kultury o bardzo szerokich zainteresowaniach) współdziałający z kresową grupę konserwatystów i niejednokrotnie podnoszący problemy moralne życia publicznego i etyczne aspekty polityki. Jako odważny myśliciel-moralista otoczony był dużym szacunkiem. Spora grupa profesorów zajmowała wysokie stanowiska w ruchu narodowym, a na ich określenie używano nawet potocznie nazwy „grupa profesorska”. W 1928 r. w najwyższych władzach - Komitecie Politycznym na 23 osoby było 7 profesorów ${ }^{44}$.

${ }^{42}$ J. Żarnowski, Inteligencja..., s. 79-80.

${ }^{43}$ Ibidem, s. 80. Por. D. Mycielska, Postawy polityczne profesorów wyższych uczelni w dwudziestoleciu międzywojennym, [w:] Inteligencja polska XIXi XX wieku. Studia, t. 4, pod red. R. Czepulis-Rastenis, Warszawa 1985, s. 294. Na temat kadry profesorskiej zob. m.in.: T. Schramm, Tworzenie uniwersytetów. Kadry profesorskie uniwersytetów w Warszawie, Poznaniu i Wilnie u progu Rzeczypospolitej, [w:] Społeczeństwo-państwo-modernizacja. Studia ofiarowane Januszowi Żarnowskiemu w siedemdziesiąta rocznice urodzin, pod red. W. Mędrzeckiego, Warszawa 2002, s. 121-141.

${ }^{44}$ Szerzej na ten temat zob. D. Mycielska, op. cit., s. 294-335. 
O odgrywaniu aktywnej roli przez środowisko naukowe nie tylko w nauce, ale również w życiu społeczno-politycznym może świadczyć chociażby protest brzeski ${ }^{45}$ czy delegacje profesorów u najwyższych władz państwowych w ważnych sprawach politycznych ${ }^{46}$. Jak podkreśla Dagmara Mycielska:

\begin{abstract}
Profesorowie, którzy zabierali głos [...] stali na stanowisku, że ich wystapienie dotyczy problemów nie politycznych ale moralnych. Ich zdaniem, wystapienie w sprawie Brześcia oznacza obronę takich wartości jak: godność człowieka, która została w więzieniu brzeskim podeptana; poczucie prawa naruszonego rzez wiele aktów z prawem niezgodnych; honoru Polaków, sprawiedliwości będacej fundamentem rządów, w imię której nie można milczeć usprawiedliwiajac się względami państwowymi, ale domagać się szybkiego wyjaśnienia i ukarania winnych ${ }^{47}$.
\end{abstract}

Uznać ich więc należy za fachowców, naukowe autorytety, nauczycieli studentów, ale przede wszystkim za inteligencką elitę, odgrywającą istotną rolę w kwestiach publicznej moralności ${ }^{48}$.

Wspomnieć wreszcie wypada chociażby o stosunkowo nielicznym środowisku intelektualistów, związanym przede wszystkim z większymi miastami kraju

${ }^{45} 18$ XII 1930 r. prasa opublikowała list otwarty profesorów Uniwersytetu Jagiellońskiego skierowany do profesora tej uczelni Adama Krzyżanowskiego, posła z listy BBWR. Czytamy w nim m.in., że: „Liczne wydarzenia, jakie zaszły w ostatnich latach, podważają - według naszego głębokiego przekonania - moralne podstawy naszego życia społecznego i politycznego w Polsce, a przez to samo zagrażają rozwojowi, a w dalszych konsekwencjach nawet istnieniu państwa polskiego". Wydarzenia towarzyszące aresztowaniu posłów określone zostały jako „hańba XX wieku”. Powołując się na odpowiedzialność moralną, wezwano go do podjęcia działań zmierzających do naprawienia krzywd i ukarania przestępców. Zob. Profesorowie Uniw. Jagiellońskiego w sprawie Brześcia, „Kurier Poznański” 1930, nr 582, s. 3.

4630 III 1939 r. miała miejsce wizyta u Prezydenta RP I. Mościckiego. Delegacji środowiska naukowego przewodził Stanisław Estreicher, a w jej skład weszli ponadto: Franciszek Bujak, Stanisław Grabski, Stefan Glaser, Zygmunt Lasocki, Tadeusz Lehr-Spławiński, Stanisław Pigoń i Cyryl Ratajski. Poruszyli oni kilka aktualnych problemów. Przede wszystkim apelowali o utworzenie rządu jedności narodowej. Ponadto upomnieli się o wygnańców politycznych (W. Witos, W. Korfanty), mówili o złej sytuacji politycznej na wsi i politycznych prześladowaniach (sprawa Berezy Kartuskiej). S. Pigoń mówił o nieprawidłowym stosunku władz do młodzieży. Zob. D. Mycielska, op. cit., s. 303; por. Na Zamku, „Gazeta Polska”, 29 III 1939, nr 88, s. 2. Ówczesne władze nie zamierzały jednak zmieniać dotychczasowej polityki. Wyartykułował to I. Mościcki, podkreślając podczas rozmowy ze środowiskiem naukowym, że jego postulaty nie mają racjonalnych podstaw, gdyż profesorowie „nie mają styczności ze społeczeństwem, nic nie wiedzą, co myśli i sądzi i czyni, on natomiast doskonale jest poinformowany, że społeczeństwo jest zadowolone, bo wszystko jak najlepiej w Polsce, a min[istra] Becka nam wszystkie państwa europejskie zazdroszczą. Także i premier jest znakomity, więc żadnych zmian nie trzeba". 1939 kwiecień 14, Warszawa. - List J. Drohojowskiego do S. Strakacza w sprawie propozycji przyjazdu I. Paderewskiego do Polski, [w:] Archiwum Polityczne Ignacego Paderewskiego, t. 4: 1935-1940, oprac. T. Jędruszczak, A. Leinwand, Wrocław-Warszawa-Kraków-Gdańsk 1974, s. 221.

${ }^{47}$ D. Mycielska, op. cit., s. 309-310.

48 Ibidem, s. 335. 
i dbającym o rozwój kulturalny oraz utrwalanie dziedzictwa narodowego. Literaci, publicyści, malarze, rzeźbiarze i inni szeroko definiowani twórcy stanowili część warstwy inteligenckiej i wykazywali już poczucie więzi oraz pewnej misji społecznej ${ }^{49}$. Stefan Żółkiewski pisał na ten temat:

Inteligencja, jak wykazywaliśmy, tak ważna dla rozwoju interesującej nas szczególnie kultury narodowej, jest u nas warstwa społeczna charakteryzująca się odrębnym sposobem i stylem życia oraz określonym miejscem $w$ spotecznym podziale pracy. Praca, która mamy namyśli, jest tzw. praca umystowa $i$ wykwalifikowana, wymagająca odpowiedniego wykształcenia, aby zapewniała źródta dochodu i środki utrzymania ${ }^{50}$.

Także służby mundurowe (przede wszystkim wojsko, ale w mniejszym stopniu również Policja Państwowa, Korpus Ochrony Granic i Straż Graniczna) skupiały znaczną część inteligencji, głównie wśród oficerów, którzy mieli pełnić zadania kulturalno-oświatowe wobec swoich podwładnych, ale i wobec ludności cywilnej. Bardzo często jednak, szczególnie w przypadku funkcjonariuszy policji i żołnierzy KOP-u założenia programowe nie były realizowane, ponieważ ograniczano się głównie do sporadycznych działań propagandowych ${ }^{51}$.

\section{Zakończenie}

Podkreślić należy, że odbudowa państwa zmieniła pozycję inteligencji, przy czym chodzi prawie wyłącznie o inteligencję etnicznie polską czy zaliczaną do narodowości polskiej. Jednocześnie znaczna część warstw posiadających, jak pisze J. Żarnowski:

chętnie przyznawała się do związków z inteligencją lub czuła się jej częścią. Od dawna już ziemianie chętnie określali się jako «inteligencja wiejska», a polska burżuazja wolała zaliczać się do inteligencji niż do «mieszczaństwa». Usprawiedliwione będzie zatem uznanie okresu międzywojennego za apogeum wplywów inteligencji. Klasa polityczna tych czasów $w$ zasadzie byta zwiazana z ta warstwa. Położenie materialne, choć dalekie od przypisywanego jej przez późniejsza legendę, byto znacznie korzystniejsze od położenia nie tylko warstwy robotniczej, ale $i$ drobnomieszczaństwa. Z kolei kultura, organizowana i upowszechniana przez państwo, opierała się na światopoglądzie inteligencji. Przede wszystkim dotyczyło to szkoły, jej programów oraz kierunku nauczania i wychowania, obejmuja-

49 I. Ihnatowicz, A. Mączak, B. Zientara, J. Żarnowski, op. cit., s. 627.

${ }^{50}$ S. Żółkiewski, Społeczne konteksty kultury literackiej na ziemiach polskich (1890-1939), do druku przygotowali: A. Brodzka, O.S. Czarnik, M. Hopfinger, Warszawa 1995, s. 104; por. E. Kraskowska, Miejsce pisarza i pisarki w kulturze międzywojnia, [w:] Metamorfozy spoteczne. Kultura i społeczeństwo, pod red. W. Mędrzeckiego i A. Zawiszewskiej, Warszawa 2012, s. 199-216; Życie i praca pisarza polskiego na podstawie ankiety Związu Zawodowego Literatów Polskich w Warszawie, Warszawa 1932, ss. 282.

${ }^{51} \mathrm{Na}$ ten temat szerzej zob. R. Litwiński, Korpus policji w II Rzeczypospolitej. Stużba i życie prywatne, Lublin 2010, s. 420-426; M. Jabłonowski, Formacja specjalna. Korpus Ochrony Pogranicza 1924-1939, Warszawa 2002/2003, s. 127-147. 
cych prawie cate młode pokolenie. W jeszcze większym stopniu inteligencja dominowała $w$ nauce i twórczości artystycznej. Trudno nie widzieć w pewnych posunięciach rzadów polskich, nawet w sprawach polityki zewnętrznej, wplywu mentalności inteligencji; wprawdzie często chodzi w tym wypadku bardziej o symbole i formy wypowiedzi niż o decyzje polityczne, ale i te ostatnie, jak się nam wydaje, nie byty wytaczone spod wplywu mentalności inteligenckiej ${ }^{52}$.

\title{
Zdaniem P. Górskiego:
}

W okresie międzywojennym dała się zauważyć trwatość inteligenckiego etosu, w którym obecne byto niedocenianie pracy $w$ sferze gospodarki. Wzór ten dominowat $w$ systemie oświatowym, szczególnie na poziomie średnim i wyższym. Na uwage zasługuje jednak przypisywanie dużego znaczenia wiedzy naukowej. Wynikało to z wpływów wzorów pozytywistycznych. Szacunek dla nauki i dostrzeganie w niej ważnego czynnika postępu ułatwiało zainteresowanie i przychylność wobec nowej dziedziny wiedzy naukowej, jaka była naukowa organizacja. Cennym w etosie inteligenckim byly również elementy odpowiedzialności społecznej, wrażliwości na biedę i dążenie do podniesienia poziomu cywilizacyjnego narodu. Inżynierowie - pionierzy naukowej organizacji - nie byli obojętni wobec tych elementów w naukowej organizacji, poszukiwali recepty na oba niedomagania ${ }^{53}$.

W latach 30. XX w. w wyniku profesjonalizacji zarządzania został wypracowany wzór menadżera. Wykreowanie takiego wzorca wskazywało nie tylko na konieczność posiadania przez inteligenta nowych kompetencji, ale świadczyło także

\begin{abstract}
o wymaganiach stawianych osobom zajmujacym stanowiska kierownicze, dotyczacych zarówno wiedzy i umiejętności organizatorskich, jak i podejmowania działań zmierzajacych do utrzymania wysokiej pozycji w przedsiębiorstwie, odpowiedniego wynagrodzenia oraz możliwości rozwoju zawodowego i awansu. Menedżer ten nie rezygnowat z realizacji celów społecznych, byty one jednak związane z przedsiębiorstwem lub branża, $w$ której pracowat. Polegaty na wychowawczym oddziaływaniu na podlegajacy mu personel oraz na dbałości o jakość świadczonych ustug i ich dostepnośs ${ }^{54}$.
\end{abstract}

Konkludując, należy zaznaczyć, że z pewnością proces budowy państwa oraz tworzenie jego aparatu zaktywizowały do działania dość szerokie grono fachowców i działaczy wśród inteligencji. Przedstawiciele inteligencji mieli wielki udział w organizowanie II Rzeczypospolitej. W tym miejscu wymienić należy chociażby:

1) uczestnictwo w odbudowie i obronie nowego państwa polskiego w $1918 \mathrm{r}$. (m.in. mobilizowanie całego społeczeństwa w obliczu zewnętrznych zagrożeń - wojna polsko-bolszewicka);

\footnotetext{
52 J. Żarnowski, Inteligencja..., s. 80-81.

${ }^{53}$ P. Górski, Między..., s. 80.

${ }^{54}$ Ibidem, s. 204-205.
} 
2) ogromne zasługi w dziele scalania państwa i jego rozwój cywilizacyjny;

3) wkład w organizację administracji centralnej, administracji ogólnej (wojewódzkiej i powiatowej), administracji specjalnej (wojsko, szkolnictwo, związki wyznaniowe, gospodarka), administracji samorządu terytorialnego, skarbowości, wymiaru sprawiedliwości;

4) udział w unifikacji i kodyfikacji prawa;

5) prace nad takimi wyzwaniami, jak: reformy socjalne, uchwalenie konstytucji, rozwiązanie najpilniejszych problemów gospodarczych i stabilizacja waluty, wprowadzenie powszechnego obowiązku szkolnego, który doprowadzić miał do wyrównania poziomu alfabetyzacji ludności między zachodnimi i wschodnimi dzielnicami kraju;

6) wkład w rozwój cywilizacyjny państwa;

7) zasługi dla rozkwitu życia naukowego, literackiego i artystycznego.

Z przywołanych form aktywności inteligencji widać explicite, że wykonywała ona tytaniczną wręcz pracę, którą można by porównać do tej, jaką zrealizowała inteligencja w województwie wołyńskim.

W ciagu niespetna 20 lat zbudowała - pisał o inteligencji na Wołyniu W. Mędrzecki-sprawnie funkcjonujacy aparat państwowy, uruchomiła i systematycznie prowadziła imponujaca sieć szkół powszechnych, stworzyła sieć szkót średnich we wszystkich wołyńskich miastach powiatowych, dała zalażki środowiska artystycznego. Wzorowo wykonała zadania, jakie postawiło przed nią odrodzone państwo. Równocześnie zbudowała instytucjonalne i materialne podwaliny wtasnego życia $[\ldots]^{55}$.

Słowa te doskonale oddają poczynania całej inteligencji polskiej podjęte w służbie państwowej II Rzeczypospolitej.

\section{BIBLIOGRAFIA}

1939 kwiecień 14, Warszawa. - List J. Drohojowskiego do S. Strakacza w sprawie propozycji przyjazdu

I. Paderewskiego do Polski, [w:] Archiwum Polityczne Ignacego Paderewskiego, t. 4: 1935-1940, oprac.

T. Jędruszczak, A. Leinwand, Wrocław-Warszawa-Kraków-Gdańsk 1974.

Ajnenkiel A., Historia Sejmu Polskiego, t. 2, cz. 2, II Rzeczpospolita, Warszawa 1989.

C.Ch., O inteligencji w znaczeniu polskim, „Dziennik Literacki” 1861, nr 100.

Cywiński B., Rodowody niepokornych, Warszawa 1971.

Dębicki Z., Kryzys inteligencji polskiej, Warszawa-Lublin-Lódź-Kraków 1918.

Górski P., Między inteligencka tradycją a menadżeryzmem. Studium kształtowania środowiska naukowej organizacji, jego ideologii i działań organizatorskich w Polsce międzywojennej, Kraków 2005.

${ }^{55}$ W. Mędrzecki, Inteligencja polska..., s. 270. 
Górski P., Profesjonalizacja administracji państwowej w Polsce 1918-1939. Uwarunkowania społeczne i kulturowe, Kraków 2011.

Gulczyński A., Ministerstwo byłej Dzielnicy Pruskiej (1919-1922), Poznań 1995.

Ihnatowicz I., Mączak A., Zientara B., Żarnowski J., Społeczeństwo polskie od X do XX wieku, Warszawa 2005.

Jabłonowski M., Formacja specjalna. Korpus Ochrony Pogranicza 1924-1939, Warszawa 2002/2003.

Janowski M., Narodziny inteligencji 1750-1831, Warszawa 2008.

Kraskowska E., Miejsce pisarza i pisarki w kulturze międzywojnia, [w:] Metamorfozy społeczne. Kultura i spoteczeństwo, pod red. W. Mędrzeckiego i A. Zawiszewskiej, Warszawa 2012.

Lechoń J., Portrety ludzi i zdarzeń, oprac. P. Kądziela, Warszawa 1997.

Leszczyński P.A, Centralna administracja wyznaniowa II RP. Ministerstwo Wyznań Religijnych i Oświecenia Publicznego, Warszawa 2006.

Litwiński R., Korpus policji w II Rzeczypospolitej. Stużba i życie prywatne, Lublin 2010.

Mędrzecki W., Inteligencja polska na Wołyniu w okresie międzywojennym, Warszawa 2005.

Micińska M., Inteligencja na rozdrożach 1864-1918, Warszawa 2008.

Mycielska D., Postawy polityczne profesorów wyższych uczelni w dwudziestoleciu międzywojennym, [w:] Inteligencja polska XIX i XX wieku. Studia, t. 4, pod red. R. Czepulis-Rastenis, Warszawa 1985.

Na Zamku, „Gazeta Polska”, 29 III 1939, nr 88.

Profesorowie Uniw. Jagiellońskiego w sprawie Brześcia, „Kurier Poznański” 1930, nr 582.

Schramm T., Tworzenie uniwersytetów. Kadry profesorskie uniwersytetów $w$ Warszawie, Poznaniu $i$ Wilnie u progu Rzeczypospolitej, [w:] Społeczeństwo-państwo-modernizacja. Studia ofiarowane Januszowi Żarnowskiemu w siedemdziesiąta rocznicę urodzin, pod red. W. Mędrzeckiego, Warszawa 2002.

Stegner T., „Postępowa demokracja” a inteligencja, [w:] Inteligencja polska XIX i XX wieku. Studia, t. 4, pod red. R. Czepulis-Rastenis, Warszawa 1985.

Ustawa z dnia 17 lutego 1922 r. o państwowej stużbie cywilnej, „Dziennik Ustaw Rzeczypospolitej Polskiej” 1922, nr 21, poz. 164.

W.R., Autostrady a nasze potrzeby wojenne, „Kurier Poranny” 1937, nr 275.

Witkowski W., Historia administracji w Polsce 1764-1989, Warszawa 2007.

Żarnowski J., Inteligencja, [w:] W. Mędrzecki, Sz. Rudnicki, J. Żarnowski, Spoleczeństwo polskie w XX wieku, Warszawa 2003.

Żarnowski J., O inteligencji polskiej lat międzywojennych, Warszawa 1965.

Żarnowski J., Społeczeństwo Drugiej Rzeczypospolitej 1918-1939, Warszawa 1973.

Żeromski S., Organizacya inteligencyi zawodowej, Warszawa-Kraków 1919.

Żółkiewski S., Społeczne konteksty kultury literackiej na ziemiach polskich (1890-1939), do druku przygotowali: A. Brodzka, O.S. Czarnik, M. Hopfinger, Warszawa 1995.

Życie i praca pisarza polskiego na podstawie ankiety Związu Zawodowego Literatów Polskich w Warszawie, Warszawa 1932.

\section{Robert Litwiński \\ POLISH INTELLIGENTSIA IN THE STATE SERVICE OF THE SECOND POLISH REPUBLIC (OUTLINE OF THE PROBLEM)}

Polish intelligentsia shaped over the nineteenth century was to fulfill various tasks. One of the owned posts. 
The euphoria of the independence regained in 1918 accompanied the concern for the proper organization of a state that did not even have a nationwide government, and several political centers pretended to be in power. The country was destroyed and famished, and the borders had to be marked out by armed forces, despite the fact that there was actually no uniform army. There was no administrative apparatus that would turn economic and social-political life into peaceful work. It is not surprising that the Polish intelligentsia had an important role to play in this case, and the functioning of the state depended primarily on the number and quality of personnel it could have at its disposal.

It should be noted that certainly the process of building the state and creating its apparatus have activated a fairly wide circle of professionals and activists among the intelligentsia, who did even titanic work in the difficult conditions of the interwar period, which was visible in the reconstruction and organization of the new Polish state and ensuring conditions for peaceful existence.

Keywords: intelligentsia, "state civil service", the Second Polish Republic. 